NBER WORKING PAPER SERIES

\title{
ALTERNATIVE CASH TRANSFER DELIVERY MECHANISMS: IMPACTS ON ROUTINE PREVENTATIVE HEALTH CLINIC VISITS IN BURKINA FASO
}

\author{
Richard Akresh \\ Damien de Walque \\ Harounan Kazianga \\ Working Paper 17785 \\ http://www.nber.org/papers/w17785
}

\author{
NATIONAL BUREAU OF ECONOMIC RESEARCH \\ 1050 Massachusetts Avenue \\ Cambridge, MA 02138 \\ January 2012
}

These data were collected for a project evaluating social protection strategies in Burkina Faso, which greatly benefited from the support of Marie-Claire Damiba, Seydou Kabré and Victorine Yameogo from the Secrétariat Permanent du Comité National de Lutte contre le SIDA et les Infections Sexuellement Transmissibles (SP-CNLS-IST) in Burkina Faso and Hans Binswanger, Nono Ayivi-Guedehoussou, Ousmane Haidara, Timothy Johnston, Mead Over and Tshiya Subayi-Cuppen at the World Bank. Data collection was supervised by Robert Ouedraogo, Jean-Pierre Sawadogo, Bambio Yiriyibin and Pam Zahonogo from the University of Ouagadougou, Department of Economics. The project is funded by the NBER Africa Project and the following World Bank trust fund grants: Strategic Impact Evaluation Fund (SIEF), Bank-Netherlands Partnership Program (BNPP), Gender Action Plan (GAP), Knowledge for Change Program (KCP), WB-DFID Evaluation of the Community Response to HIV and AIDS, and Luxembourg Poverty Reduction Partnership (LPRP). The authors would also like to thank Pascaline Dupas and Adam Wagstaff as well as participants at the NBER Africa workshop in Zanzibar for helpful comments on an earlier draft. Finally, the authors thank Emilie Bagby, German Caruso, Igor Cunha, Christine Jachetta, Moussa Kone, Marleen Marra, and Nga Thi Viet Nguyen for their research assistance. The findings, interpretations, and conclusions expressed in this paper are entirely those of the authors. They do not necessarily represent the views of the World Bank, its Executive Directors, or the countries they represent. The views expressed herein are those of the authors and do not necessarily reflect the views of the National Bureau of Economic Research.

NBER working papers are circulated for discussion and comment purposes. They have not been peerreviewed or been subject to the review by the NBER Board of Directors that accompanies official NBER publications.

(C) 2012 by Richard Akresh, Damien de Walque, and Harounan Kazianga. All rights reserved. Short sections of text, not to exceed two paragraphs, may be quoted without explicit permission provided that full credit, including $\odot$ notice, is given to the source. 
Alternative Cash Transfer Delivery Mechanisms: Impacts on Routine Preventative Health Clinic Visits in Burkina Faso

Richard Akresh, Damien de Walque, and Harounan Kazianga

NBER Working Paper No. 17785

January 2012

JEL No. I15,I38,J13,O15

\begin{abstract}
$\underline{\text { ABSTRACT }}$
We conducted a unique randomized experiment to estimate the impact of alternative cash transfer delivery mechanisms on household demand for routine preventative health services in rural Burkina Faso. The two-year pilot program randomly distributed cash transfers that were either conditional or unconditional and were given to either mothers or fathers. Families under the conditional cash transfer schemes were required to obtain quarterly child growth monitoring at local health clinics for all children under 60 months old. There were no such requirements under the unconditional programs. Compared with control group households, we find that conditional cash transfers significantly increase the number of preventative health care visits during the previous year, while unconditional cash transfers do not have such an impact. For the conditional cash transfers, transfers given to mothers or fathers showed similar magnitude beneficial impacts on increasing routine visits.
\end{abstract}

\author{
Richard Akresh \\ University of Illinois at Urbana-Champaign \\ Department of Economics \\ 1407 West Gregory Drive \\ David Kinley Hall, Room 214 \\ Urbana, IL 61801 \\ akresh@illinois.edu \\ Damien de Walque \\ The World Bank \\ Development Research Group \\ 1818 H Street, NW \\ Washington, DC 20433 \\ ddewalque@worldbank.org
}

\author{
Harounan Kazianga \\ Department of Economics \\ Oklahoma State University \\ Business 324 \\ Stillwater, OK 74078 \\ and William Spears School of Business \\ harounan.kazianga@okstate.edu
}




\section{Introduction}

Poor health is widespread among children in low-income countries. Often, such ill health is coupled with poor access to health care, either because of supply-side or demand-side constraints. These poor health outcomes negatively affect physical growth and cognitive development, with potential long-term consequences. For example, children who are in poor health are less likely to enroll in school, or enter school later, and when they enroll they tend to perform worse than children in good health (Moock and Leslie 1986; Brooker, Hall, and Bundy 1999; Glewwe, Jacoby, and King 2001). This in turn affects productivity later in life (Dasgupta 1993; Strauss and Thomas 1995; Schultz 2001). It is estimated that illness incidence and other health risks prevent approximately 200 million children in low income countries from reaching their full potential in cognitive development (Grantham-McGregor et al. 2007). Obviously, identifying mechanisms that could improve health outcomes among children will have large payoffs, not only at the individual level, but also in term of overall economic progress as well.

Conditional cash transfer (CCT) programs are now one of the most popular government welfare interventions in developing countries. ${ }^{1}$ These programs transfer resources to poor households conditional on the family taking measures to increase the health and human capital of their children (predominantly enrolling their children in school and taking them for regular health care visits). Unconditional cash transfer (UCT) programs do not impose these conditionality constraints. CCT programs represent a "top-down" approach in which outside organizations decide what is best for poor children and provide incentives to their parents to achieve these objectives. In contrast, UCT programs assume that, once a budget constraint is

\footnotetext{
${ }^{1}$ Numerous countries in Latin America, as well as in Asia have implemented such programs (Fiszbein and Schady 2009). In Africa, several CCT pilot programs (in South Africa and Kenya) have been implemented but focus exclusively on orphans and HIV households and have not yet been rigorously evaluated, while other pilot programs (in Malawi and Morocco) are currently being evaluated (see Baird, McIntosh, and Ozler 2011 for information about the Malawi evaluation) but focus mainly on educational outcomes or adolescent children.
} 
relaxed, parents are in a better position to make appropriate decisions regarding their child's human capital. CCT programs are also more costly per recipient to administer than UCT programs because of the costs associated with monitoring conditions. Unconditional cash transfers act through increased income, so that health outcomes should improve as long as the income elasticity of demand for health is positive and marginal productivity of health care is positive (Parker and Wong, 1998). Mounting evidence shows both types of transfers improve child health outcomes (for CCTs in Colombia (Attanasio, Gomez, Heredia, and Vera-Hernandez 2005), Ecuador (Paxson and Schady 2008), Nicaragua (Maluccio and Flores 2005; Macours, Schady, and Vakis 2008); and for UCTs in South Africa (Case and Deaton 1998; Case, Hosegood, and Lund 2005; Duflo 2003)), but the evidence on which mechanisms-conditionality or income effects- are playing a role in driving the impacts is more limited. ${ }^{2}$

In this paper, we present evidence of the impacts of a unique cash transfer pilot program in rural Burkina Faso, the Nahouri Cash Transfers Pilot Project (NCTPP), on the take-up of routine preventative health clinic visits. The NCTPP incorporated a random experimental design to evaluate the relative effectiveness of the following four cash transfer programs targeting poor households in rural Burkina Faso: conditional cash transfers given to fathers, conditional cash transfers given to mothers, unconditional cash transfers given to fathers, and unconditional cash transfers given to mothers. Our evaluation focuses on health utilization for children 0 to 59 months old, in particular their visits to health clinics for routine preventative care. Even by African standards, child health outcomes in Burkina Faso are considered to be poor. In 2003,

\footnotetext{
${ }^{2}$ However, not all impact studies show consistently positive results for these programs, and differences tend to depend on the specific details about the cash transfer program, the age range of the child studied, the evaluation method, and whether the evaluations were measuring short or medium term impacts. Even for outcomes that were directly conditioned upon, such as preventative health clinic visits, evaluations for Chile (Galasso 2006), Ecuador (Paxson and Schady 2008), and Nicaragua (Maluccio and Flores 2005) show no significant change in the number of visits to the health clinic for preventative reasons, while there were positive impacts on routine health check-ups in Colombia (Attanasio et al. 2005), Honduras (Morris, Flores, Olinto, and Medina 2004), and Jamaica (Levy and Ohls 2007).
} 
38.7 percent of children under 59 months were 2 standard deviations below the reference population for height-for-age, 18.6 percent for weight-for-height and 37.7 percent for weight-forage (INSD/ORC Macro, 2004). Similarly, 38 percent of children in that age group experienced some form of fever or respiratory infection in the two weeks preceding the national Demographic and Health Survey. Among children who had been ill, only 30 percent received any care from a health professional (INSD/ORC Macro, 2004).

We find that children under age five in families that received conditional cash transfers have 0.43 more visits to the health clinic for routine preventative care during the previous year compared to children in control households, a 49 percent increase compared to the mean in the control group. We find similar magnitude beneficial impacts for children in families where the mother or father received conditional cash transfers, indicating that at least when the transfers are conditional, the gender of the cash transfer recipient is not a critical factor influencing the frequency of routine health facility visits. In contrast, we do not find beneficial effects from unconditional cash transfers that are given to either mothers or fathers. This highlights the point that at least for this particular outcome of routine preventative health clinic visits, conditionality is more important than transfer recipient gender in increasing health clinic utilization for children.

Our experimental design has several distinctive features differentiating it from other studies. First, we randomly test conditional and unconditional cash transfers in the same environment, which allows us to determine whether the key factor driving impacts is an income effect or conditionality. ${ }^{3}$ Second, unlike many cash transfer programs that pay the transfers to

\footnotetext{
${ }^{3}$ A recent study by de Brauw and Hoddinott (2007) makes use of administrative errors in Mexico to try to untangle how much of any observed program impact is due to the program's income transfers and how much is due to the conditionality forcing households to undertake specific behaviors in order to receive the funds. Baird, McIntosh and
} 
mothers with the hope mothers will spend the money more wisely, we randomly selected mothers or fathers to receive the payments. Hence we contribute to the long-standing question on the effects of resources controlled by the mother or the father on a child's human capital.

The remainder of the paper is organized as follows. Section 2 describes the cash transfer pilot program as well as its experimental design and presents some descriptive statistics from the household survey. Section 3 discusses our empirical identification strategy and Section 4 presents main results. Section 5 concludes.

\section{Burkina Faso Nahouri Cash Transfer Pilot Project}

\subsection{Program Design}

The pilot cash transfer program was conducted in Nahouri province in southern Burkina Faso, located approximately 100 miles from the capital, Ouagadougou. The 75 villages in Nahouri province that each have a primary school were randomly allocated to the following five groups (see Figure 1, panel A): (i) conditional cash transfers given to the father (CCTF), (ii) conditional cash transfers given to the mother (CCTM), (iii) unconditional cash transfers given to the father (UCTF), (iv) unconditional cash transfers given to the mother (UCTM), and (v) a control group. There were 15 villages in each treatment arm and in the control group. Based on our experience with previous randomized program evaluations in Burkina Faso, as well as qualitative focus groups we conducted in Nahouri province, we believed that transparency in the randomization process was critical for maintaining a household's participation in the surveys and to guarantee the local authorities' support. Therefore, the village-level treatment randomization took place during a public meeting in the Nahouri provincial capital in which each village was represented by their local leaders.

Özler (2011) also report results from a randomized experiment in Malawi comparing conditional and unconditional cash transfers, but their target population are adolescent girls and they mainly focus on education outcomes. 
In the next stage, in each of the 60 villages that were randomly selected to receive a cash transfer program, all poor eligible households were present for a participatory lottery to randomly assign those households to either receive or not receive the particular type of transfer allocated to that village. To determine whether a household was eligible (based on their poverty status) to take part in the lottery, immediately prior to the baseline survey, we conducted an extended household census in every village to collect information from each household about household living structure (cement or mud brick walls, metal or straw roof, flooring, access to latrine), household asset ownership (plow, cart, draft animals, motorcycle, radio), whether the head of household ever attended school, whether the household grows cotton, and whether there was a weekly market in the village. We combined this information with a Burkina Faso nationally representative household survey to calculate a predicted consumption level for each household and compare that with the national poverty line to determine whether a household is considered poor and subsequently is eligible to receive the cash transfer. Given the government transfer program's limited budget, in consultation with village leaders, we decided that randomization was the fairest way to determine which poor eligible households receive a transfer, and everyone was aware that not all poor households in a given village would be receiving a transfer during the pilot program.

We conducted three rounds of surveys (baseline, one-year follow-up, two-year follow-up) in June 2008, June 2009, and June 2010, interviewing all poor households eligible to receive a transfer in each of the treatment villages and who had been randomly selected to receive the transfer. In each of these four groups of 15 villages, we interviewed approximately 540 poor households randomly selected to receive transfers. The control group consisted of 615 randomly 
selected poor households that did not receive a cash transfer in the 15 control villages where no households received cash transfers.

Among households randomly assigned to a CCT scheme, for their children under age six, the conditions imposed were quarterly visits to the local health clinic for child growth monitoring, while for children age seven to fifteen, the conditions were school enrollment with an attendance rate above 90 percent each quarter. In the villages randomly assigned to conditional cash transfers, satisfaction of the conditions was assessed using a family booklet in which the school teachers and the health workers signed and stamped the booklet for a given child to confirm school attendance and health visits, respectively. Further, in the CCT villages, local village committees, which had received specific training, randomly selected 20 percent of the booklets and verified the information reported in those with data from the school attendance registers and the health center visits register.

For families randomly assigned to a UCT program, the mother or father received a quarterly stipend for each child without conditions. For each child under age six, in the CCT and UCT programs, the mother or father would receive 1000 FCFA per quarter, for a total of 4000 FCFA per year. Using the exchange rate during the 2008 baseline of 415 FCFA $=\$ 1$ USD, the annual transfer was worth approximately $\$ 9.64$, which is 9 percent of household per capita expenditures. For each child age 7 to 10 (or in grades 1 to 4), the mother or father would receive 2000 FCFA per quarter (8000 FCFA per year), while for each child age 11 to 15 (or in grades 5 or higher), the mother or father would receive 4000 FCFA per quarter (16,000 FCFA per year). ${ }^{4}$ There was no household transfer cap amount, so that each age eligible child could participate irrespective of the composition of the family. The transfers were made in cash during a quarterly

\footnotetext{
${ }^{4}$ To minimize child fostering in response to the program introduction and reduce any potential sample attrition (see Akresh 2009 for evidence on the relationship between income shocks and child fostering), eligibility for cash transfers was based only on the children present in the household at the time of the baseline survey.
} 
visit conducted by the program staff. Cash transfers were disbursed during the academic school year 2008-2009 (October 2008 to June 2009) and 2009-2010 (October 2009 to June 2010). The program design assumes that each of the treatment groups would receive equal amounts of resources per capita over the two-year transfer program period if households randomly allocated to the conditional cash transfers fully satisfied the conditions.

Meetings were also organized between the central government and the provincial health and education authorities to ensure the full participation of school administrators (principals and teachers) and health administrators (doctors and nurses) in the program. This included ensuring their role in verifying the cash transfer conditionality. However, no other changes were made to and no additional government funds were provided for the supply of education or health services.

\subsection{Descriptive Statistics}

Households in the Nahouri region are predominantly subsistence farmers growing sorghum and groundnuts and have mean annual per capita expenditures of approximately \$111 USD.

Summary statistics in Table 1 show that on average, there are 7.0 members in each household, of whom 1.5 are children under 60 months and 2.3 are children age 5 to 15 . Focusing on the children under 60 months old that are used in this paper's analysis, 49.4 percent of them are female and their average age is 30.7 months old ${ }^{5}$ Only 18.5 percent of these children's parents (father or mother) have ever been enrolled in school. On average, children have 1.03 routine preventative health clinic visits per year, although younger children (0-23 months) have more visits (1.43) than older (24-59 months) children $(0.80){ }^{6}$

\footnotetext{
${ }^{5}$ Note that of the poor eligible surveyed households in the treatment and control villages, only 1618 households are used in the health analysis for this paper, because the remaining households did not have any children under 60 months old.

${ }^{6}$ The American Academy of Pediatrics recommends the following schedule for preventive childhood health care visits: birth, 2 months, 4 months, 6 months, 9 months, 12 months, 15 months, 18 months, 24 months, 36 months, 48 months, 60 months.
} 
The health care system in rural Burkina Faso is relatively underdeveloped. In the 75 survey villages, not every village has a health clinic, but the median distance to the nearest health clinic is only two kilometers (average distance is 2.85 kilometers). This is below the Burkina Faso national average distance to a basic health care center, which is 7.5 kilometers (Ministry of Health 2007). In addition, there are no statistically significant differences across treatment and control groups in the average distance to a health clinic.

Access to basic health care remains poor in Burkina Faso. In 2007, only 36 percent of the population had access to basic health care (Ministry of Heath 2010). The available data also suggest that the health system is under-staffed. In 2009, the ratios of total population to health care professionals indicate there are 22,522 people per physician, 94,564 per pharmacist, and 2,892 people per nurse (Ministry of Health 2010). The poor access to health services translates into lower utilization of health care, especially preventive health care. In rural Burkina Faso, it is estimated that only 60 percent of baby deliveries are attended by a trained health care provider, with large variations across regions (INSD/ORC Macro 2010). Noticeable exceptions include immunization coverage (more than 80 percent of children in rural areas) and utilization of prenatal care (around 94 percent of pregnant women in rural area).

In Table 2, we use baseline data to test the balance of the randomization experiment. We first present the mean of the specific variable measured at the baseline for the control group and each of the four treatment arms. In the subsequent columns, we present p-values from a Wald test comparing the treatment arm with control group. Finally, in the last column (under the control group heading), we present the p-value for an F-test of the joint test that the means of the five groups are equal. Results show balance across characteristics for children, parents, and measures of supply-side health clinic quality. The main dependent variable used in this paper, 
routine preventative health clinic visits, was only collected in the final survey round, so we are unable to examine whether the variable exhibits balance in the baseline round (pre-intervention) across the treatment and control groups. ${ }^{7}$

Household attrition was very low between the baseline and one-year follow-up survey (1.42 percent), and increases slightly when comparing the baseline and two-year follow-up survey (4.62 percent). In Table 3, we explore the relative differences between attritor and nonattritor households. Column 1 presents means of the household-level characteristics from the baseline survey for the sample of households that were followed from the baseline to the twoyear follow-up survey (non-attritors). Column 2 presents means for the sample of attritor households, and column 3 presents the average difference in characteristics between attritors and non-attritors, as well as a test of whether the difference is statistically significant. Results suggest that attrition is not likely random, as attritors are more likely to come from smaller households, with fewer adults, are younger, have fewer wives, and are more likely to be female headed households. However, what is more relevant for our analysis is whether attrition differs across treatment and control groups. In columns 4 to 7 of Table 3, we present difference-in-differences regressions for each characteristic comparing the difference between attritors and non-attritors in each specific treatment arm with the same difference between attritors and non-attritors in the control group, and we find few significant differences.

\section{Empirical Identification Strategy}

The key question we want to answer is whether cash transfers increased the frequency of routine preventative visits to health facilities by young children in recipient households. The experimental design provides a strong identification strategy and allows us to attribute any

\footnotetext{
${ }^{7}$ However, we are able to test baseline balance for other health outcomes for which we do have three rounds of data, such as the probability the child was sick during the past month, health clinic utilization, and illness duration, and all of these exhibit balance across randomized treatment and control groups in the baseline.
} 
differences in outcome indicators (frequency of preventative visits to health clinics) between the treatment and control groups to the impact of the program. Because precise questions about the purpose of the visits to the health clinics were only included in the last round of data collection (Round 3), we cannot use a difference-in-differences model. We rely on the program randomization to identify causal impacts of alternative cash transfer delivery mechanisms on routine health clinic visits. Since Table 2 indicates that health behaviors and supply-side measures of health clinic quality were well balanced across the five study groups at baseline, this provides support for our identification strategy. We focus on the program effects on the treated households.

We start by pooling the treatment arms to estimate two distinct specifications. First, we consider households that were either randomly selected to receive conditional cash transfers or randomly selected to receive unconditional cash transfers (see Panel B of Figure 1). This approach combines into one group the conditional cash transfers given to fathers or mothers and into a second group the unconditional cash transfers given to fathers or mothers. With this specification we focus on whether the conditionality matters and we ignore the intra-household allocation aspects of the design. Formally, the regression is specified as follows:

$$
y_{i h}=\beta_{0}+\alpha_{1} C C T_{h}+\alpha_{2} U C T_{h}+\beta_{1} X_{i h}+\varepsilon_{i h}
$$

where $y_{i h}$ is the number of routine preventative health clinic visits for child $i$ in household $h$, $C C T_{h}$ and $U C T_{h}$ are treatment indicators that take the value one if a child lives in a household $h$ that was randomly selected to receive respectively, conditional or unconditional cash transfers and is zero otherwise, $X_{i h}$ is a vector of child characteristics (gender and age) and $\varepsilon$ is an error 
term. ${ }^{8}$ The estimated impact for conditional cash transfers is given by $\alpha_{1}$ and for unconditional cash transfers by $\alpha_{2}$.

Second, we consider households that were either randomly assigned to receive the stipends via the mother or via the father (Panel $\mathrm{C}$ of Figure 2). This approach combines into one group the conditional and unconditional cash transfers given to fathers and into a second group the conditional and unconditional cash transfers given to mothers. When estimating this specification, we focus on intra-household allocation (whether paying the stipends to the mother or the father leads to different outcomes), and we ignore the role that conditionality might play. We estimate the following regression:

$$
y_{i h}=\beta_{0}+\alpha_{1} C T F_{h}+\alpha_{2} C T M_{h}+\beta_{1} X_{i h}+\varepsilon_{i h}
$$

where $C T F_{h}$ indicates a household $h$ that is randomly selected to receive cash transfer given to fathers, $C T M_{h}$ indicates a household $h$ that is randomly selected to receive cash transfer given to mothers, and all of the other variables are as defined previously. In Equation 2, $\alpha_{1}$ and $\alpha_{2}$ represent the impact of cash transfers to fathers and to mothers, respectively.

It is plausible that mothers and fathers react differently not only to the transfers, but also to the conditionality. In order to test this hypothesis, we allow the four treatment groups to enter separately in the regression. The resulting specification is:

$$
y_{i h}=\beta_{0}+\alpha_{1} C C T F_{h}+\alpha_{2} \operatorname{CCTM}_{h}+\alpha_{3} \operatorname{UCTF}_{h}+\alpha_{4} U C T M_{h}+\beta_{1} X_{i h}+\varepsilon_{i h}
$$

where the four treatment groups are defined as binary variables and are represented by $\mathrm{CCTF}_{h}$ (conditional cash transfers to fathers), $\mathrm{CCTM}_{h}$ (conditional cash transfers to mothers), $\mathrm{UCTF}_{h}$ (unconditional cash transfers to fathers) and $\mathrm{UCTM}_{h}$ (unconditional cash transfers to mothers).

\footnotetext{
${ }^{8}$ Correlation among the error terms of children in a given village experiencing the same shocks might bias the ordinary least squares standard errors downward, so in all regressions we cluster the standard errors at the village level.
} 
All of the other variables are defined as before. The estimated impact of each treatment scheme is given by the associated coefficient, $\alpha_{1}, \alpha_{2}, \alpha_{3}$, and $\alpha_{4}$.

\section{Empirical Results}

In Table 4, we present results from estimating the three equations discussed above for routine preventative health clinic visits. Each regression includes controls for the child's gender and year of birth cohort. All regressions are restricted to children under 60 months old. Column 1 focuses on the comparison between conditional and unconditional cash transfers, while Column 2 focuses on the comparison between transfers given to fathers or mothers. Finally, in Column 3 , we examine the impact of all four treatment groups separately.

We find that conditional cash transfers have a larger impact on routine health clinic visits than unconditional cash transfers. Young children less than 60 months old in households that receive conditional cash transfers have 0.43 more routine preventative health clinic visits in the preceding year compared to comparable children in the control villages. This represents an increase of 42 percent compared to the average number of routine visits. We find no significant impact of unconditional cash transfers on these routine health visits, and relative to unconditional cash transfers, the impact on routine health clinic visits is significantly larger for conditional transfers. We are able to strongly reject equality between the coefficients on the conditional and unconditional variables with a p-value of 0.002 .

Turning to evaluate the impact of cash transfers given to fathers compared to mothers, in column 2, we estimate a regression with the same dependent variable but with independent variables indicating if a child was in a household where the cash transfers were given to fathers or to mothers. Overall, children in households that received cash transfers (either to the father or mother) receive more routine preventative health clinic visits than children in control 
households, although neither coefficient is statistically significant. Although the point estimate is larger for children in households where the mother received the transfer $(0.235)$, we cannot reject equality between that coefficient and the coefficient for cash transfer to fathers $(0.070)$ with a pvalue of the test of equality of 0.35 .

The above results where the cash transfers are grouped by the presence or absence of conditionality (Column 1) and the transfer recipient's gender (Column 2) potentially hide the fact that there could be significant differences between how conditionality interacts with a recipient's gender. To explore this further, in Column 3, we estimate Equation 3 in which we include four indicator variables corresponding to each of the four different treatments (conditional cash transfers to fathers, conditional cash transfers to mothers, unconditional cash transfers to fathers, and unconditional cash transfers to mothers). Results highlight that conditionality is critical for improving take-up of routine preventative health clinic visits. Children living in households where the cash transfers were conditional and given to mothers have 0.446 more preventative health clinic visits and the coefficient is statistically significant at the 5 percent level. For children living in households where the cash transfers were conditional and given to fathers, the results indicate they have 0.415 more routine health clinic visits, although the coefficient is not statistically significant at standard levels. In testing the equality of these two coefficients, we are not able to reject equality, with the p-value equal to 0.901 . These results for conditional cash transfers contrast with those for unconditional cash transfers. Children living in households that received unconditional cash transfers given to fathers or living in households that received unconditional cash transfers given to mothers show no significant impact on the take-up of routine preventative health clinic visits. The point estimate is positive, but small for unconditional cash transfers to mothers and is actually negative for fathers, indicating children in 
these two treatment arms are no better off compared to comparable children in the control households. Formally testing equality between the coefficients shows that the impact of conditional cash transfers to mothers is larger than both unconditional cash transfers to mothers or fathers. The impact of conditional cash transfers to fathers is larger than unconditional cash transfers to fathers and mothers, although we can only reject equality with a p-value of 0.156 for the test with mothers.

In the next three tables, we examine if there is a heterogeneous impact of cash transfers based on child gender (Table 5), child age (Table 6), or the baseline poverty status of the household (Table 7). In Table 5, impacts of alternative cash transfers are fairly consistent across boys and girls. Conditional cash transfers have a larger impact than unconditional cash transfers for both boys and girls, and we are able to reject equality in both regressions (p-value equal to 0.019 for boys and 0.002 for girls). We find no statistically significant impacts on routine health clinic visits when the cash transfers are grouped by mother or father (columns 2 and 5). We find suggestive evidence that conditional cash transfers to fathers have a larger impact on routine health clinic visits for girls (an additional 0.580 visits), while conditional cash transfers to mothers have a larger impact on health clinic visits for boys (an additional 0.505 visits). Conditional cash transfers to mothers still have a significant impact for girls, and we are not able to reject equality between the impact of conditional cash transfers to fathers or mothers (for either boys or girls). Unconditional cash transfers to fathers or mothers show no significant positive impact for either boys or girls.

Table 6 presents separate results for younger (ages 0 to 23 months) and older (ages 24-59 months) children. All of the impacts of cash transfers on routine preventative health clinic visits discussed previously are being driven by older children. This might be explained by the fact that 
parents in Burkina Faso are less likely to bring older children for routine preventative care visits. Indeed, as noted previously, on average, younger children have more visits (1.43) than older children $(0.80)$, so that, while routine visits for young children might already be frequent for young children in the absence of the transfers, the transfers might have had a relatively larger impact on the less frequent visits for older children.

We find no statistically significant impact of cash transfers on routine health clinic visits for younger children. To put this in perspective, this means that young children (0-23 months) in control households are as equally likely to have gone to a health clinic for a routine visit as a young child in a treatment household. This contrasts with older children for whom there are large impacts of the cash transfers on the number of routine health clinic visits. Conditional cash transfers yield larger impacts on increasing the number of routine preventative health clinic visits compared to unconditional cash transfers, with an increase of 0.592 visits for the older children, representing an increase of 74 percent over the mean number of visits. For older children, cash transfers to mothers or to fathers show increases in routine health clinic visits, although only the coefficient on the mother's variable is statistically significant. Finally, conditional cash transfers to fathers or mothers show larger impacts for the older children, increasing the number of health clinic visits by 0.630 and 0.558 visits, respectively. This represents increases of 79 and 70 percent, respectively for cash transfers to fathers or mothers that are conditional, compared to the average number of routine health clinic visits children of this age receive.

In Table 7, we do not find any significant differences between the impacts for cash transfers given to extremely poor or less poor households. As discussed in Section 2.1, recall that all households that were eligible to receive the cash transfers were below the estimated national poverty line. The further distinction in Table 7 is comparing extremely poor and less poor 
households, which might explain the absence of differential impacts by poverty status. ${ }^{9}$

Conditional cash transfers increase the number of routine preventative health care visits for children in those households and the household's poverty status does not alter this relationship (columns 1 and 4). There are no significant improvements on health clinic visits for the regressions when we group transfers to mothers or transfers to fathers. As before, conditionality is driving our observed results and the gender of the recipient does not matter, and the estimated impacts are similar between extremely poor and less poor households.

\section{Conclusions}

This paper presents evidence of the health impacts from a cash transfer pilot program in rural Burkina Faso, the Nahouri Cash Transfer Pilot Program (NCTPP). Our evaluation focuses on routine preventative health clinic visits for children 0 to 5 years old. The NCTPP incorporated a random experimental design to evaluate the relative effectiveness of the following modalities for delivering cash transfers: conditional versus unconditional and transfers to mothers versus fathers. Families under the conditional cash transfer schemes were required to obtain child growth monitoring at local health clinics for all young children.

Our results indicate that children in families that received conditional cash transfers had an additional 0.43 routine preventative health clinic visits during the previous year compared to children in the control households. These results contrast with those for unconditional cash transfers given to either fathers or mothers, which showed no beneficial impacts. As long as the transfers were conditional, we did not find any significant difference between whether the money was given to fathers or to mothers, indicating that at least for routine health clinic visits, the cash transfer recipient's gender is not a critical factor influencing outcomes. One limitation of our

\footnotetext{
${ }^{9}$ To make this additional distinction in Table 7, extremely poor households are defined as being below the median household per capita expenditure level in the baseline survey.
} 
analysis is that the health clinic visits are self-reported by the parents. In future work, we will investigate more objectively measured child health outcomes such as anthropometrics and infant mortality.

From a policy perspective, conditional cash transfers appear to have stronger beneficial impacts on increasing the number of routine health care visits for children. This finding should be balanced with the additional administrative and logistical costs implied by imposing and verifying the conditionality. For the outcome analyzed in this paper - routine preventative health clinic visits - the gender of the recipient does not seem to affect critically the impact of the cash transfers on those health outcomes. Such a conclusion, however, needs to be included in a larger analysis of other health and schooling outcomes as well as other age ranges for the children.

Indeed, the NSPP is a broad social protection pilot program that covers all children until age 15 in the eligible households and aims to improve both their schooling and health outcomes. It should be emphasized that while we focus on children under age 5 in this analysis, those children could have benefited from the (larger) transfers received for their older siblings. It is not clear that by only implementing the part of the intervention targeted for young children ( 0 to 59 months), similar health results would necessarily be obtained. 


\section{References}

Akresh, Richard. 2009. "Flexibility of Household Structure: Child Fostering Decisions in Burkina Faso.” Journal of Human Resources, 44(4), 976-997.

Attanasio, Orazio, Luis Carlos Gomez, Patricia Heredia, and Marcos Vera-Hernandez. 2005. "The Short-Term Impact of a Conditional Cash Subsidy on Child Health and Nutrition in Colombia.” Report Summary: Familias 03, Institute for Fiscal Studies, London.

Baird, Sarah, Craig McIntosh, and Berk Özler. 2011. "Cash or Condition? Evidence from a Cash Transfer Experiment." Quarterly Journal of Economics, forthcoming.

Brooker, Simon, Andrew Hall, and Donald A.P. Bundy. 1999. "Short Stature and the Age of Enrollment in Primary School: Studies in Two African Countries." Social Science and Medicine, 48(5), 675-682.

Case, Anne and Angus Deaton. 1998. "Large Cash Transfers to the Elderly in South Africa." Economic Journal, 108(450), 1330-1361.

Case, Anne, Victoria Hosegood, and Frances Lund. 2005. "The Reach and Impact of Child Support Grants: Evidence from KwaZulu-Natal.” Development Southern Africa, 22(4), 467-482.

Dasgupta, Partha. 1993. An Inquiry into Well-Being and Destitution. Oxford: Clarendon Press.

de Brauw, Alan, and John Hoddinott. 2007. "Must Conditional Cash Transfer Programs Be Conditioned To Be Effective? The Impact of Conditioning Transfers on School Enrollment in Mexico.” International Food Policy Research Institute, manuscript.

Duflo, Esther 2003. "Grandmothers and Granddaughters: Old-Age Pensions and Intrahousehold Allocation in South Africa." World Bank Economic Review, 17(1), 1-25.

Fiszbein, Ariel and Norbert Schady 2009. Conditional Cash Transfers: Reducing Present and Future Poverty. World Bank Policy Research Report. World Bank: Washington, DC.

Galasso, Emanuela. 2006. "With Their Effort and One Opportunity: Alleviating Extreme Poverty in Chile." World Bank, manuscript.

Glewwe, Paul, Hannan Jacoby, and Elizabeth King. 2001. "Early Childhood Nutrition and Academic Achievement: A Longitudinal Analysis." Journal of Public Economics, 81(3), 345-368.

Grantham-McGregor, Sally, Yin Bun Cheung, Santiago Cueto, Paul Glewwe, Linda Richter, and Barbara Strupp. 2007. "Development Potential in the First 5 Years for Children in Developing Countries.” The Lancet, 369(9555), 60-70. 
INSD/ORC Macro. 2004. Enquête Démographique et de Santé 2003. Ouagadougou, Ministère de l'économie et du développement, Burkina Faso.

INSD/ORC Macro. 2010. Enquête Démographique et de Santé 2010: Rapport Préliminaire. Ouagadougou, Ministère de l'économie et du développement, Burkina Faso.

Levy, Dan and James Ohls. 2007. "Evaluation of Jamaica's PATH Program: Final Report." Mathematica Policy Research.

Macours, Karen, Norbert Schady, and Reno Vakis. 2008. "Cash Transfers, Behavioral Changes, and the Cognitive Development of Young Children: Evidence from a Randomized Experiment.” World Bank Policy Research Working Paper 4759.

Maluccio, John and Rafael Flores. 2005. "Impact Evaluation of the Pilot Phase of the Nicaraguan Red de Proteción Social." International Food and Policy Research Institute, Food Consumption and Nutrition Division Discussion Paper 141.

Ministry of Health, Burkina Faso. 2010. Tableaux de Bord de la Sante. Ouagadougou, Burkina Faso.

Moock, Peter R. and Joanne Leslie. 1986. "Childhood Malnutrition and Schooling in the Terai Region of Nepal.” Journal of Development Economics, 20(1), 33-52.

Morris, Saul, Rafael Flores, Pedro Olinto, and Juan Manuel Medina. 2004. "Monetary Incentives in Primary Health Care and Effects on Use and Coverage of Preventive Health Care Interventions in Rural Honduras: Cluster Randomized Trial.” The Lancet, 364(9450), 2030-2037.

Parker, Susan W. and Rebeca Wong. 1998. "Household Income and Health Care Expenditures in Mexico." Health Policy, 40(3), 237-255.

Paxson, Christina and Norbert Schady. 2008. "Does Money Matter? The Effects of Cash Transfers on Child Health and Development in Rural Ecuador." World Bank Policy Research Working Paper 4226.

Schultz, T. Paul. 2001. "Productive Benefits of Improving Health: Evidence from Low Income Countries." Yale University, manuscript.

Strauss, John and Duncan Thomas. 1995. "Human Resources: Empirical Modeling of Household and Family Decisions." In Handbook of Development Economics, T.N. Srinivasan and J. Behrman, editors. North Holland: Amsterdam. 
Table 1: Summary Statistics of Burkina Faso Nahouri Cash Transfer Pilot Project (NCTPP) Evaluation Data

\begin{tabular}{lcc}
\hline Variable & Mean & $\begin{array}{c}\text { Standard } \\
\text { Deviation } \\
(2)\end{array}$ \\
\hline Household Characteristics & $(1)$ & \\
Household size & 7.023 & 3.294 \\
Number of children under 60 months & 1.474 & 0.952 \\
Number of children age 5 to 15 years & 2.317 & 1.772 \\
Proportion either parent ever enrolled in school & 0.185 & 0.388 \\
Household expenditures per capita (in FCFA) & 46257 & 66105 \\
& & \\
Child Characteristics & & \\
Child age (in months) & 30.74 & 16.85 \\
Child gender (1=Female) & 0.494 & 0.500 \\
Routine Preventative Health Clinic Visits & 1.025 & 1.823 \\
& & \\
\hline Number of Households & 1618 & \\
Number of Children & 2559 & \\
\hline
\end{tabular}

Notes: Household characteristics are based on the 1618 households that were eligible to receive cash transfers (treatment and control groups) and that have children under 60 months old. Child characteristics are based on the 2559 children under 60 months old in these households. Per capita household expenditures are measured in FCFA (415 FCFA=\$1). Data source: Nahouri Cash Transfer Pilot Project (NCTPP) evaluation data from 2010. 
Table 2: Baseline Means and Randomization Balance

\begin{tabular}{|c|c|c|c|c|c|c|c|c|c|c|}
\hline & \multicolumn{2}{|c|}{ CCTF } & \multicolumn{2}{|c|}{ CCTM } & \multicolumn{2}{|c|}{ UCTF } & \multicolumn{2}{|c|}{ UCTM } & \multicolumn{2}{|c|}{ Control } \\
\hline & Mean & p-value & Mean & p-value & Mean & p-value & Mean & p-value & Mean & p-value \\
\hline \multicolumn{11}{|l|}{ Child and Parent Characteristics: } \\
\hline Child is female & 0.507 & 0.525 & 0.488 & 0.993 & 0.454 & 0.191 & 0.489 & 0.974 & 0.488 & 0.317 \\
\hline Child age in months & 29.745 & $0.095 *$ & 29.450 & 0.177 & 29.070 & 0.413 & 28.154 & 0.839 & 28.336 & 0.276 \\
\hline Head of household is female & 0.144 & 0.732 & 0.162 & 0.855 & 0.125 & 0.342 & 0.106 & 0.108 & 0.156 & 0.353 \\
\hline Proportion either parent ever enrolled & 0.155 & 0.806 & 0.179 & 0.501 & 0.184 & 0.420 & 0.200 & 0.298 & 0.143 & 0.824 \\
\hline Number of wives of household head & 1.056 & 0.564 & 1.064 & 0.496 & 1.121 & 0.122 & 1.141 & $0.078 *$ & 1.010 & 0.380 \\
\hline Household size & 6.535 & 0.157 & 6.422 & 0.276 & 6.897 & $0.016 * *$ & 6.569 & 0.125 & 6.049 & 0.189 \\
\hline Marital status=Monogamous & 0.593 & 0.761 & 0.576 & 0.378 & 0.579 & 0.451 & 0.622 & 0.554 & 0.605 & 0.509 \\
\hline Marital status=Polygamous & 0.207 & 0.480 & 0.214 & 0.391 & 0.239 & 0.108 & 0.226 & 0.215 & 0.184 & 0.547 \\
\hline Marital status $=$ Single & 0.200 & 0.802 & 0.210 & 0.971 & 0.181 & 0.449 & 0.152 & 0.105 & 0.211 & 0.362 \\
\hline Ethnic group $=$ Kassena & 0.570 & 0.969 & 0.370 & 0.217 & 0.553 & 0.943 & 0.711 & 0.307 & 0.564 & 0.209 \\
\hline Ethnic group $=$ Nankana $/$ Farfarse & 0.383 & 0.915 & 0.487 & 0.464 & 0.271 & 0.545 & 0.144 & 0.119 & 0.366 & 0.134 \\
\hline Ethnic group $=$ Mossi & 0.028 & 0.537 & 0.073 & 0.754 & 0.114 & 0.443 & 0.089 & 0.561 & 0.057 & 0.393 \\
\hline Ethnic subgroup $=$ Nakomse & 0.578 & 0.971 & 0.505 & 0.564 & 0.609 & 0.745 & 0.585 & 0.919 & 0.574 & 0.927 \\
\hline Religion = Muslim & 0.215 & 0.963 & 0.262 & 0.437 & 0.221 & 0.907 & 0.257 & 0.546 & 0.211 & 0.917 \\
\hline Religion $=$ Christian & 0.278 & 0.737 & 0.308 & 0.926 & 0.222 & 0.147 & 0.270 & 0.563 & 0.302 & 0.469 \\
\hline Religion $=$ Animist & 0.498 & 0.849 & 0.414 & 0.465 & 0.544 & 0.536 & 0.459 & 0.835 & 0.478 & 0.701 \\
\hline Number of wives of HH head's father & 2.180 & 0.939 & 2.209 & 0.709 & 2.508 & $0.097 *$ & 2.174 & 0.979 & 2.171 & 0.568 \\
\hline Number of children of $\mathrm{HH}$ head's father & 9.089 & 0.980 & 9.215 & 0.798 & 9.835 & 0.347 & 8.955 & 0.839 & 9.075 & 0.875 \\
\hline \multicolumn{11}{|l|}{ Village Level Health Clinic Variables } \\
\hline Villages per health clinic & 9.53 & 0.593 & 10.57 & 0.885 & 9.73 & 0.782 & 12.08 & 0.425 & 10.31 & 0.411 \\
\hline Number of days a doctor is present & 5.091 & 0.871 & 4.455 & 0.576 & 4.375 & 0.582 & 4.125 & 0.515 & 5.250 & 0.818 \\
\hline Number of nurses & 3.467 & 0.406 & 3.286 & 0.352 & 3.333 & 0.458 & 3.500 & 0.574 & 4.000 & 0.863 \\
\hline Childhood nutritional/growth counseling offered & 0.867 & 0.184 & 0.929 & 0.370 & 0.933 & 0.366 & 0.692 & $0.089 *$ & 1.000 & 0.296 \\
\hline Vaccines offered & 0.933 & 0.371 & 0.929 & 0.370 & 0.933 & 0.366 & 0.769 & 0.164 & 1.000 & 0.461 \\
\hline Nutritional supplements offered & 0.733 & 0.796 & 0.929 & 0.309 & 0.667 & 0.545 & 0.462 & $0.051 *$ & 0.769 & $0.069 *$ \\
\hline Health epidemics & 0.667 & 0.231 & 0.571 & 0.565 & 0.538 & 0.656 & 0.636 & 0.370 & 0.462 & 0.648 \\
\hline Source of funding for clinic (patient, govt., NGO) & 1.200 & 0.321 & 1.214 & 0.383 & 1.267 & 0.542 & 1.692 & 0.287 & 1.385 & 0.127 \\
\hline
\end{tabular}


Table 3: Relative Differences Between Attriting and Non-Attriting Households

\begin{tabular}{|c|c|c|c|c|c|c|c|}
\hline Variables: & $\begin{array}{c}\text { Non- } \\
\text { Attritors } \\
(\mathrm{n}=2622)\end{array}$ & $\begin{array}{l}\text { Attritors } \\
(\mathrm{n}=127)\end{array}$ & $\begin{array}{c}\text { Mean } \\
\text { Difference }\end{array}$ & $\begin{array}{c}\text { CCT } \\
\text { Diff in } \\
\text { Diff }\end{array}$ & $\begin{array}{c}\text { UCT } \\
\text { Diff in } \\
\text { Diff }\end{array}$ & $\begin{array}{c}\text { CTF Diff } \\
\text { in Diff }\end{array}$ & $\begin{array}{l}\text { CTM Diff } \\
\text { in Diff }\end{array}$ \\
\hline & (1) & (2) & (3) & (4) & $(5)$ & (6) & (7) \\
\hline HH expenditures per & 46036 & 50228 & 4192 & -4240 & -10172 & -7525 & -10589 \\
\hline \# children $<60$ months & $\begin{array}{l}1.095 \\
(0.021)\end{array}$ & $\begin{array}{c}(400 J) \\
1.118 \\
(0.070)\end{array}$ & $\begin{array}{l}0.023 \\
(0.097)\end{array}$ & $\begin{array}{l}-0.083 \\
(0.163)\end{array}$ & $\begin{array}{l}-0.064 \\
(0.189)\end{array}$ & $\begin{array}{l}-0.169 \\
(0.161)\end{array}$ & $\begin{array}{c}0.062 \\
(0.180)\end{array}$ \\
\hline Number of adults & $\begin{array}{c}3.123 \\
(0.033)\end{array}$ & $\begin{array}{c}2.575 \\
(0.119)\end{array}$ & $\begin{array}{l}-0.548^{* * *} \\
(0.153)\end{array}$ & $\begin{array}{l}-0.005 \\
(0.328)\end{array}$ & $\begin{array}{c}0.156 \\
(0.319)\end{array}$ & $\begin{array}{l}-0.014 \\
(0.331)\end{array}$ & $\begin{array}{c}0.170 \\
(0.320)\end{array}$ \\
\hline Household size & $\begin{array}{c}6.551 \\
(0.062)\end{array}$ & $\begin{array}{c}5.323 \\
(0.214)\end{array}$ & $\begin{array}{l}-1.228 * * * \\
(0.284)\end{array}$ & $\begin{array}{c}0.524 \\
(0.475)\end{array}$ & $\begin{array}{c}0.478 \\
(0.518)\end{array}$ & $\begin{array}{c}0.309 \\
(0.471)\end{array}$ & $\begin{array}{c}0.848^{*} \\
(0.501)\end{array}$ \\
\hline HH head literate & $\begin{array}{c}0.157 \\
(0.007)\end{array}$ & $\begin{array}{c}0.189 \\
(0.035)\end{array}$ & $\begin{array}{c}0.032 \\
(0.033)\end{array}$ & $\begin{array}{c}0.007 \\
(0.078)\end{array}$ & $\begin{array}{l}-0.046 \\
(0.094)\end{array}$ & $\begin{array}{l}-0.001 \\
(0.079)\end{array}$ & $\begin{array}{l}-0.031 \\
(0.093)\end{array}$ \\
\hline HH head age & $\begin{array}{l}45.25 \\
(0.286)\end{array}$ & $\begin{array}{l}42.23 \\
(1.329)\end{array}$ & $\begin{array}{l}-3.02 * * \\
(1.330)\end{array}$ & $\begin{array}{c}0.122 \\
(2.986)\end{array}$ & $\begin{array}{c}1.521 \\
(3.209)\end{array}$ & $\begin{array}{l}-1.935 \\
(3.014)\end{array}$ & $\begin{array}{c}3.821 \\
(2.982)\end{array}$ \\
\hline HH head educated & $\begin{array}{c}0.157 \\
(0.007)\end{array}$ & $\begin{array}{c}0.142 \\
(0.031)\end{array}$ & $\begin{array}{l}-0.015 \\
(0.033)\end{array}$ & $\begin{array}{l}-0.078 \\
(0.071)\end{array}$ & $\begin{array}{l}-0.106 \\
(0.075)\end{array}$ & $\begin{array}{l}-0.020 \\
(0.060)\end{array}$ & $\begin{array}{c}-0.181 * * \\
(0.086)\end{array}$ \\
\hline HH head gender & $\begin{array}{c}1.136 \\
(0.007)\end{array}$ & $\begin{array}{l}1.189 \\
(0.037)\end{array}$ & $\begin{array}{c}0.053 * \\
(0.032)\end{array}$ & $\begin{array}{c}0.092 \\
(0.106)\end{array}$ & $\begin{array}{c}0.085 \\
(0.095)\end{array}$ & $\begin{array}{c}0.173^{*} \\
(0.093)\end{array}$ & $\begin{array}{l}-0.025 \\
(0.113)\end{array}$ \\
\hline Polygamous & $\begin{array}{c}0.218 \\
(0.008)\end{array}$ & $\begin{array}{c}0.102 \\
(0.027)\end{array}$ & $\begin{array}{l}-0.116^{* * *} \\
(0.037)\end{array}$ & $\begin{array}{c}0.049 \\
(0.062)\end{array}$ & $\begin{array}{c}0.016 \\
(0.064)\end{array}$ & $\begin{array}{c}0.028 \\
(0.063)\end{array}$ & $\begin{array}{c}0.053 \\
(0.063)\end{array}$ \\
\hline Monogamous & $\begin{array}{c}0.593 \\
(0.010)\end{array}$ & $\begin{array}{c}0.042 \\
(0.661)\end{array}$ & $\begin{array}{c}0.069 \\
(0.045)\end{array}$ & $\begin{array}{l}-0.137 \\
(0.098)\end{array}$ & $\begin{array}{l}-0.160 \\
(0.099)\end{array}$ & $\begin{array}{l}-0.171^{*} \\
(0.090)\end{array}$ & $\begin{array}{l}-0.112 \\
(0.115)\end{array}$ \\
\hline Single & $\begin{array}{c}0.189 \\
(0.008)\end{array}$ & $\begin{array}{c}0.236 \\
(0.038)\end{array}$ & $\begin{array}{c}0.036 \\
(0.047)\end{array}$ & $\begin{array}{c}0.088 \\
(0.101)\end{array}$ & $\begin{array}{c}0.144 \\
(0.094)\end{array}$ & $\begin{array}{c}0.143 \\
(0.094)\end{array}$ & $\begin{array}{c}0.059 \\
(0.109)\end{array}$ \\
\hline Ethnic group=Kassena & $\begin{array}{c}0.554 \\
(0.010)\end{array}$ & $\begin{array}{c}0.591 \\
(0.044)\end{array}$ & $\begin{array}{c}0.037 \\
(0.045)\end{array}$ & $\begin{array}{l}-0.063 \\
(0.153)\end{array}$ & $\begin{array}{l}-0.015 \\
(0.152)\end{array}$ & $\begin{array}{l}-0.033 \\
(0.148)\end{array}$ & $\begin{array}{l}-0.009 \\
(0.161)\end{array}$ \\
\hline Ethnic group=Nankana & $\begin{array}{c}0.334 \\
(0.009)\end{array}$ & $\begin{array}{c}0.260 \\
(0.039)\end{array}$ & $\begin{array}{l}-0.074 * \\
(0.043)\end{array}$ & $\begin{array}{c}0.186 \\
(0.145)\end{array}$ & $\begin{array}{c}0.065 \\
(0.140)\end{array}$ & $\begin{array}{c}0.092 \\
(0.146)\end{array}$ & $\begin{array}{c}0.135 \\
(0.144)\end{array}$ \\
\hline Religion=Muslim & $\begin{array}{c}0.231 \\
(0.008)\end{array}$ & $\begin{array}{c}0.260 \\
(0.039)\end{array}$ & $\begin{array}{c}0.029 \\
(0.038)\end{array}$ & $\begin{array}{c}0.124 \\
(0.107)\end{array}$ & $\begin{array}{c}0.116 \\
(0.111)\end{array}$ & $\begin{array}{c}0.123 \\
(0.104)\end{array}$ & $\begin{array}{c}0.113 \\
(0.115)\end{array}$ \\
\hline Religion $=$ Christian & $\begin{array}{c}0.272 \\
(0.009)\end{array}$ & $\begin{array}{c}0.378 \\
(0.043)\end{array}$ & $\begin{array}{l}0.106^{* * *} \\
(0.041)\end{array}$ & $\begin{array}{c}0.022 \\
(0.090)\end{array}$ & $\begin{array}{l}-0.021 \\
(0.128)\end{array}$ & $\begin{array}{c}0.078 \\
(0.082)\end{array}$ & $\begin{array}{l}-0.102 \\
(0.117)\end{array}$ \\
\hline Religion=Animist & $\begin{array}{c}0.484 \\
(0.010)\end{array}$ & $\begin{array}{c}0.354 \\
(0.043)\end{array}$ & $\begin{array}{l}-0.130 * * * \\
(0.045)\end{array}$ & $\begin{array}{l}-0.129 \\
(0.095)\end{array}$ & $\begin{array}{l}-0.100 \\
(0.134)\end{array}$ & $\begin{array}{l}-0.180^{*} \\
(0.098)\end{array}$ & $\begin{array}{l}-0.018 \\
(0.111)\end{array}$ \\
\hline $\begin{array}{l}\text { \#wives of HH head's } \\
\text { father }\end{array}$ & $\begin{array}{c}2.247 \\
(0.038)\end{array}$ & $\begin{array}{c}2.214 \\
(0.165)\end{array}$ & $\begin{array}{l}-0.033 \\
(0.177)\end{array}$ & $\begin{array}{l}-0.550 \\
(0.334)\end{array}$ & $\begin{array}{l}-0.246 \\
(0.475)\end{array}$ & $\begin{array}{l}-0.369 \\
(0.392)\end{array}$ & $\begin{array}{l}-0.450 \\
(0.370)\end{array}$ \\
\hline $\begin{array}{l}\text { \#kids of HH head's } \\
\text { father }\end{array}$ & $\begin{array}{l}9.253 \\
(0.139)\end{array}$ & $\begin{array}{c}8.714 \\
(0.531)\end{array}$ & $\begin{array}{l}-0.539 \\
(0.641)\end{array}$ & $\begin{array}{l}-0.208 \\
(1.510)\end{array}$ & $\begin{array}{l}1.556 \\
(1.316)\end{array}$ & $\begin{array}{c}0.995 \\
(1.343)\end{array}$ & $\begin{array}{l}-0.1000 \\
(1.721)\end{array}$ \\
\hline
\end{tabular}

Notes: *significant at 10\%; ** significant at 5\%;*** significant at $1 \%$. Column 1 presents means of householdlevel characteristics from the baseline survey for the sample of households that were followed from the baseline to the two-year follow-up survey (non-attritors). Column 2 presents means for the sample of attritor households, and column 3 presents the average difference in characteristics between attritors and non-attritors. The treatment arms are abbreviated as CCT (conditional cash transfer), UCT (unconditional cash transfer), CTF (cash transfer given to fathers), and CTM (cash transfer given to mothers). Columns 4-7 test for differential impacts of attrition between treatment and control groups. Specifically, for each characteristic, we estimate difference-in-differences regressions comparing attritors and non-attritors for the treatment (CCT, UCT, CTF, CTM) and control groups. Data source: Nahouri Cash Transfer Pilot Project (NCTPP) data from 2010. 
Table 4: Impact of Cash Transfers on Routine Preventative Health Clinic Visits

Dependent Variable: Routine Health Clinic Visits

\begin{tabular}{ll}
\hline Conditional Cash Transfer (CCT) & $(1)$ \\
& $0.431^{* *}$ \\
Unconditional Cash Transfer (UCT) & {$[0.205]$} \\
& -0.079 \\
Cash Transfer Fathers (CTF) & {$[0.195]$}
\end{tabular}

Cash Transfer Fathers (CTF)

Cash Transfer Mothers (CTM)

Conditional Cash Transfer Fathers (CCTF)

Conditional Cash Transfer Mothers (CCTM)

Unconditional Cash Transfer Fathers (UCTF)

Unconditional Cash Transfer Mothers (UCTM)
0.070
$[0.209]$
0.235

[0.201]
0.415

[0.258]

$0.446^{* *}$

[0.223]

$-0.216$

[0.200]

0.046

[0.231]

\begin{tabular}{lccc} 
Child Age \& Gender Fixed Effects? & Yes & Yes & Yes \\
\hline Number of observations & 2559 & 2559 & 2559 \\
\hline$P$-value testing equality between CCT and UCT: & 0.002 & & \\
$P$-value testing equality between Fathers and Mothers: & & 0.346 & \\
$P$-value testing equality between CCTF and CCTM: & & & 0.901 \\
$P$-value testing equality between CCTF and UCTF: & & & 0.008 \\
$P$-value testing equality between CCTF and UCTM: & & & 0.156 \\
$P$-value testing equality between CCTM and UCTF: & & & 0.001 \\
$P$-value testing equality between CCTM and UCTM: & & & 0.076 \\
$P$-value testing equality between UCTF and UCTM: & & & 0.190 \\
\hline
\end{tabular}

Notes: Robust standard errors in brackets, clustered at the village level. *significant at $10 \%$;** significant at 5\%; *** significant at $1 \%$. All regressions are restricted to children under 60 months old and include child age fixed effects and child gender dummies. Data source: Nahouri Cash Transfer Pilot Project (NCTPP) evaluation data from 2010. 
Table 5: Impact of Cash Transfers on Routine Preventative Health Clinic Visits, By Gender

\begin{tabular}{|c|c|c|c|c|c|c|}
\hline \multirow{2}{*}{$\begin{array}{l}\text { Dependent Variable: } \\
\text { Routine Health Clinic Visits }\end{array}$} & \multicolumn{3}{|c|}{ Boys } & \multicolumn{3}{|c|}{ Girls } \\
\hline & $(1)$ & (2) & (3) & (4) & (5) & (6) \\
\hline CCT & $\begin{array}{l}0.389 \\
{[0.242]}\end{array}$ & & & $\begin{array}{l}0.477 * * \\
{[0.222]}\end{array}$ & & \\
\hline UCT & $\begin{array}{l}-0.045 \\
{[0.229]}\end{array}$ & & & $\begin{array}{l}-0.106 \\
{[0.207]}\end{array}$ & & \\
\hline Cash Transfer Fathers (CTF) & & $\begin{array}{l}0.010 \\
{[0.232]}\end{array}$ & & & $\begin{array}{l}0.136 \\
{[0.235]}\end{array}$ & \\
\hline Cash Transfer Mothers (CTM) & & $\begin{array}{l}0.283 \\
{[0.240]}\end{array}$ & & & $\begin{array}{l}0.190 \\
{[0.210]}\end{array}$ & \\
\hline CCT-Father & & & $\begin{array}{l}0.244 \\
{[0.290]}\end{array}$ & & & $\begin{array}{l}0.580^{*} \\
{[0.301]}\end{array}$ \\
\hline CCT-Mother & & & $\begin{array}{l}0.505^{*} \\
{[0.269]}\end{array}$ & & & $\begin{array}{l}0.384^{*} \\
{[0.223]}\end{array}$ \\
\hline UCT-Father & & & $\begin{array}{l}-0.169 \\
{[0.234]}\end{array}$ & & & $\begin{array}{l}-0.260 \\
{[0.203]}\end{array}$ \\
\hline UCT-Mother & & & $\begin{array}{l}0.075 \\
{[0.272]}\end{array}$ & & & $\begin{array}{l}0.023 \\
{[0.251]}\end{array}$ \\
\hline Child Age \& Gender Fixed Effects? & Yes & Yes & Yes & Yes & Yes & Yes \\
\hline Number of observations & 1296 & 1296 & 1296 & 1263 & 1263 & 1263 \\
\hline $\begin{array}{l}P \text {-value testing } C C T=U C T: \\
P \text {-value testing } C T F=C T M:\end{array}$ & 0.019 & 0.140 & & 0.002 & 0.790 & \\
\hline$P$-value testing CCTF $=C C T M$ : & & & 0.354 & & & 0.497 \\
\hline$P$-value testing $C C T F=U C T F$ : & & & 0.100 & & & 0.003 \\
\hline$P$-value testing $C C T F=U C T M:$ & & & 0.547 & & & 0.076 \\
\hline$P$-value testing $C C T M=U C T F$ : & & & 0.003 & & & 0.001 \\
\hline$P$-value testing $C C T M=U C T M:$ & & & 0.102 & & & 0.128 \\
\hline$P$-value testing $U C T F=U C T M:$ & & & 0.281 & & & 0.190 \\
\hline
\end{tabular}

Notes: Robust standard errors in brackets, clustered at the village level. *significant at $10 \%$; ** significant at 5\%; *** significant at $1 \%$. All regressions are restricted to children under 60 months old and include child age fixed effects and child gender dummies. The treatment arms are abbreviated as CCT (conditional cash transfer), UCT (unconditional cash transfer), CTF (cash transfer given to fathers), CTM (cash transfer given to mothers), CCT-Father (conditional cash transfer given to fathers), CCT-Mother (conditional cash transfer given to mothers), UCTFather (unconditional cash transfer given to fathers), and UCT-Mother (unconditional cash transfer given to mothers). Data source: Nahouri Cash Transfer Pilot Project (NCTPP) evaluation data from 2010. 
Table 6: Impact of Cash Transfers on Routine Preventative Health Clinic Visits, By Child Age

\begin{tabular}{|c|c|c|c|c|c|c|}
\hline \multirow{2}{*}{$\begin{array}{l}\text { Dependent Variable: } \\
\text { Routine Health Clinic Visits }\end{array}$} & \multicolumn{3}{|c|}{$\begin{array}{l}\text { Young Children (0-23 } \\
\text { Months) }\end{array}$} & \multicolumn{3}{|c|}{$\begin{array}{l}\text { Old Children (24-59 } \\
\text { Months) }\end{array}$} \\
\hline & $(1)$ & (2) & (3) & $(4)$ & (5) & (6) \\
\hline CCT & $\begin{array}{l}0.098 \\
{[0.498]}\end{array}$ & & & $\begin{array}{l}0.592 * * * \\
{[0.203]}\end{array}$ & & \\
\hline UCT & $\begin{array}{l}-0.516 \\
{[0.485]}\end{array}$ & & & $\begin{array}{l}0.143 \\
{[0.155]}\end{array}$ & & \\
\hline Cash Transfer Fathers (CTF) & & $\begin{array}{l}-0.406 \\
{[0.488]}\end{array}$ & & & $\begin{array}{l}0.307 \\
{[0.192]}\end{array}$ & \\
\hline Cash Transfer Mothers (CTM) & & $\begin{array}{l}-0.086 \\
{[0.498]}\end{array}$ & & & $\begin{array}{l}0.391^{* *} \\
{[0.172]}\end{array}$ & \\
\hline CCT-Father & & & $\begin{array}{l}-0.030 \\
{[0.492]}\end{array}$ & & & $\begin{array}{l}0.630^{* *} \\
{[0.308]}\end{array}$ \\
\hline CCT-Mother & & & $\begin{array}{l}0.198 \\
{[0.554]}\end{array}$ & & & $\begin{array}{l}0.558^{* *} \\
{[0.218]}\end{array}$ \\
\hline UCT-Father & & & $\begin{array}{l}-0.704 \\
{[0.501]}\end{array}$ & & & $\begin{array}{l}0.033 \\
{[0.151]}\end{array}$ \\
\hline UCT-Mother & & & $\begin{array}{l}-0.347 \\
{[0.506]}\end{array}$ & & & $\begin{array}{l}0.244 \\
{[0.206]}\end{array}$ \\
\hline Child Age \& Gender Fixed Effects? & Yes & Yes & Yes & Yes & Yes & Yes \\
\hline Number of observations & 897 & 897 & 897 & 1662 & 1662 & 1662 \\
\hline$P$-value testing $C C T=U C T$ : & 0.013 & & & 0.024 & & \\
\hline$P$-value testing $C T F=C T M:$ & & 0.196 & & & 0.671 & \\
\hline$P$-value testing CCTF $=C C T M$ : & & & 0.515 & & & 0.832 \\
\hline$P$-value testing $C C T F=U C T F:$ & & & 0.010 & & & 0.051 \\
\hline$P$-value testing $C C T F=U C T M:$ & & & 0.236 & & & 0.247 \\
\hline$P$-value testing $C C T M=U C T F$ : & & & 0.016 & & & 0.013 \\
\hline$P$-value testing $C C T M=U C T M$ : & & & 0.144 & & & 0.216 \\
\hline$P$-value testing $U C T F=U C T M:$ & & & 0.211 & & & 0.280 \\
\hline
\end{tabular}

Notes: Robust standard errors in brackets, clustered at the village level. *significant at $10 \%$; ** significant at $5 \% ; * * *$ significant at $1 \%$. All regressions are restricted to children under 60 months old and include child age fixed effects and child gender dummies. The treatment arms are abbreviated as CCT (conditional cash transfer), UCT (unconditional cash transfer), CTF (cash transfer given to fathers), CTM (cash transfer given to mothers), CCT-Father (conditional cash transfer given to fathers), CCT-Mother (conditional cash transfer given to mothers), UCTFather (unconditional cash transfer given to fathers), and UCT-Mother (unconditional cash transfer given to mothers). Data source: Nahouri Cash Transfer Pilot Project (NCTPP) evaluation data from 2010. 
Table 7: Impact of Cash Transfers on Routine Preventative Health Clinic Visits, By Baseline Poverty Status

\begin{tabular}{|c|c|c|c|c|c|c|}
\hline \multirow{2}{*}{$\begin{array}{l}\text { Dependent Variable: } \\
\text { Routine Health Clinic Visits }\end{array}$} & \multicolumn{3}{|c|}{ Poor Households } & \multicolumn{3}{|c|}{ Non-poor Households } \\
\hline & $(1)$ & $(2)$ & (3) & $(4)$ & $(5)$ & $(6)$ \\
\hline CCT & $\begin{array}{l}0.450 * \\
(0.239)\end{array}$ & & & $\begin{array}{l}0.389 * \\
(0.234)\end{array}$ & & \\
\hline UCT & $\begin{array}{l}-0.132 \\
(0.215)\end{array}$ & & & $\begin{array}{l}0.068 \\
(0.222)\end{array}$ & & \\
\hline Cash Transfer Fathers (CTF) & & $\begin{array}{l}0.015 \\
(0.233)\end{array}$ & & & $\begin{array}{l}0.199 \\
(0.240)\end{array}$ & \\
\hline Cash Transfer Mothers (CTM) & & $\begin{array}{l}0.204 \\
(0.228)\end{array}$ & & & $\begin{array}{l}0.281 \\
(0.223)\end{array}$ & \\
\hline CCT-Father & & & $\begin{array}{l}0.453 \\
(0.302)\end{array}$ & & & $\begin{array}{l}0.324 \\
(0.298)\end{array}$ \\
\hline CCT-Mother & & & $\begin{array}{l}0.447^{*} \\
(0.270)\end{array}$ & & & $\begin{array}{l}0.434^{*} \\
(0.260)\end{array}$ \\
\hline UCT-Father & & & $\begin{array}{l}-0.300 \\
(0.207)\end{array}$ & & & $\begin{array}{l}0.053 \\
(0.274)\end{array}$ \\
\hline UCT-Mother & & & $\begin{array}{l}0.029 \\
(0.264)\end{array}$ & & & $\begin{array}{l}0.081 \\
(0.240)\end{array}$ \\
\hline Child Age \& Gender Fixed Effects? & Yes & Yes & Yes & Yes & Yes & Yes \\
\hline Number of observations & 1731 & 1731 & 1731 & 828 & 828 & 828 \\
\hline$P$-value testing $C C T=U C T:$ & 0.005 & & & 0.102 & & \\
\hline$P$-value testing $C T F=C T M:$ & & 0.364 & & & 0.685 & \\
\hline$P$-value testing CCTF $=C C T M$ : & & & 0.985 & & & 0.715 \\
\hline$P$-value testing $C C T F=U C T F:$ & & & 0.006 & & & 0.387 \\
\hline$P$-value testing CCTF $=U C T M:$ & & & 0.182 & & & 0.387 \\
\hline$P$-value testing CCTM $=U C T F:$ & & & 0.002 & & & 0.173 \\
\hline$P$-value testing CCTM $=$ UCTM: & & & 0.142 & & & 0.148 \\
\hline P-value testing UCTF =UCTM: & & & 0.145 & & & 0.913 \\
\hline
\end{tabular}

Notes: Robust standard errors in brackets, clustered at the village level. *significant at $10 \%$; ** significant at 5\%; *** significant at $1 \%$. All regressions are restricted to children under 60 months old and include child age fixed effects and child gender dummies. All households that were eligible to receive the cash transfers were below the estimated national poverty line. The further distinction in this table is comparing extremely poor and less poor households. Extremely poor households are defined as being below the median household per capita expenditure level in the baseline survey. The treatment arms are abbreviated as CCT (conditional cash transfer), UCT (unconditional cash transfer), CTF (cash transfer given to fathers), CTM (cash transfer given to mothers), CCT-Father (conditional cash transfer given to fathers), CCT-Mother (conditional cash transfer given to mothers), UCT-Father (unconditional cash transfer given to fathers), and UCTMother (unconditional cash transfer given to mothers). Data source: Nahouri Cash Transfer Pilot Project (NCTPP) evaluation data from 2010. 
Figure 1: Summary of Treatment and Control Group Randomization Plan

Panel A: Experimental Design for Pilot Program

75 villages

(2775

households)

15 villages

(540 households)

Randomized

CCT to Father
15 villages (540 households)

Randomized

CCT to Mother
15 villages

(540 households)

Randomized

UCT to Mother
15 villages

(615 households)

Randomized to

Control Group

Panel B: Conditional Transfers versus Unconditional Transfers Comparison

\begin{tabular}{|l|l|l|}
\hline $\begin{array}{l}\text { 30 villages } \\
\text { (1080 households) } \\
\text { Randomized to CCT }\end{array}$ & $\begin{array}{l}30 \text { villages } \\
\text { (1080 households }) \\
\text { Randomized to } \\
\text { UCT }\end{array}$ \\
\hline
\end{tabular}

Panel C Transfers to Fathers versus Transfers to Mothers Comparison

\begin{tabular}{|l|l|l|}
\hline $\begin{array}{l}30 \text { villages } \\
\text { (1080 households }) \\
\text { Randomized to } \\
\text { Fathers }\end{array}$ & $\begin{array}{l}30 \text { villages } \\
(1080 \text { households }) \\
\text { Randomized to } \\
\text { Mothers }\end{array}$ \\
\hline
\end{tabular}

